\title{
Sensory quality of Coffea arabica L. genotypes influenced by postharvest processing
}

\section{Ivan de Paiva Barbosa ${ }^{1^{*}}$, Antonio Carlos Baião de Oliveira ${ }^{2}$, Renato Domiciano Silva Rosado ${ }^{1}$, Ney Sussumu Sakiyama ${ }^{1}$, Cosme Damião $\mathrm{Cruz}^{1}$ and Antônio Alves Pereira ${ }^{3}$}

\begin{abstract}
The specialty coffee market has grown significantly in the past decades and has several cultivars with productive potential. The objective of this study was to evaluate the sensory profile of the beverage produced from Coffea arabica L. genotypes based on postharvest processing and to identify cultivars with the greatest genetic potential for coffee cultivation in the city of Araponga, Minas Gerais, Brazil. The experiment was a randomized complete block design with two replicates and 11 genotypes with different levels of resistance to rust. The sensory profile demonstrated an interaction between the genotype and the processing technique. Five of the genotypes presented total scores above 85 points according to the SCAA protocol. Moreover, two of these genotypes yielded heightened sensory notes after undergoing dry processing. The selection of coffee genotypes should consider the level of technology involved in the drying of the coffee beans, which preserves the potential quality of the beverage.
\end{abstract}

Keywords: Beverage quality, Coffea arabica, correlation network, sensory attributes, radar chart.

\section{INTRODUCTION}

Brazil is the largest producer of coffee in the world and is responsible for exporting approximately $70 \%$ of the world's global supply. Different coffeegrowing regions produce different types of coffee beverages, which helps meet the different global demands for taste and price.

In recent years, the demand for specialty coffees has increased annually by approximately $15 \%$, compared to an increase of only $2 \%$ for coffee commodities (Costa and Bessa 2014). In general, specialty coffees differ from ordinary coffees due to the absence of defects and their different qualitative attributes. The more differentiated a specialty coffee beverage and the better its sensory quality, the greater its commercial value. This segment of the market represents approximately $12 \%$ of the international coffee beverage market (Costa and Bessa 2014).

Coffee bean quality is directly influenced by the postharvest processing methodology since the coffee bean is a fruit susceptible to deterioration. Postharvest processing can be accomplished through either dry-process or wet-process methods (Teixeira et al. 2015). The selected processing method will determine the profitability of the coffee activity. The selection of method will also depend on several factors, such as the climatic conditions of the region,
Crop Breeding and Applied Biotechnology 19(4), 428-435, 2019 Brazilian Society of Plant Breeding. Printed in Brazil http://dx.doi.org/10.1590/198470332019v19n4a60

.


technology, consumer preferences, water use granted by the federal government, and the availability of wastewater treatment technologies (Borém 2008).

Araponga city has a historical precedent in coffee production and has shown great potential in the production of specialty coffees (Proença 2018). Therefore, the characterization of the beverage quality expressed by distinct genotypes submitted to different postharvest processing could influence the local coffee industry.

Thus, the objective of this work was to evaluate the sensory profile of the beverage from rust-resistant Coffea arabica genotypes to characterize them into different postharvest processing methods (wet-processed and dry-processed coffee) and to identify genotypes with greater sensory quality potential for coffee cultivation in Araponga city.

\section{MATERIAL AND METHODS}

The field experiment was carried out in the Araponga region (lat $20^{\circ} 38^{\prime} 48^{\prime \prime} \mathrm{S}$, long $42^{\circ} 30^{\prime} 41^{\prime \prime} \mathrm{W}$, alt $1100 \mathrm{~m}$ asl) in the state of Minas Gerais, Brazil. The design was a randomized complete block design (RCBD) with two replications, a spacing of $2.50 \times 0.60 \mathrm{~m}$, and 50 plants per plot. The "cherry" coffee samples were collected from ten uniform and adjacent plants in the useful parcel of the experiment in June 2016. The Araponga MG1, Catiguá MG1, Catiguá MG2, MGS Catiguá 3, Oeiras MG 6851, Paraiso MGH419-1, Pau-Brasil MG1, and Sacramento MG1 cultivars and the H419-3-37-16-4-1 elite progeny were developed by the Genetic Improvement Program of the Coffee Company of the Agricultural Research Company of Minas Gerais (EPAMIG) in partnership with the Federal University of Viçosa (UFV). The Catucaí Amarelo 24/137 cultivar developed by the Procafé Foundation had some degree of resistance to rust. The Catuaí Vermelho IAC 144 cultivar, which was developed by the Instituto Agronômico de Campinas (IAC), was susceptible to rust. The experiments were conducted using typical cultural practices used in the cultivation of arabica coffee (Guimarães et al. 1999, Sakiyama et al. 2015), except for the chemical control of rust.

The fruits of the species Coffea arabica L. were separated at the maturation stage for harvest. This separation was especially important since these species normally can flower more than once in a given season. Thus, approximately 40 liters of coffee berries were collected at the cherry stage for each of the 22 plots.

Samples were collected and processed on the same day and washed using a 500-liter polyethylene box filled with water so that lower-density, undersized, and deformed fruits could be easily removed. Some undesirable fruits that remained in the samples, such as immature beans, overripened beans, and dried fruits, were discarded to eliminate possible contamination with immature and deteriorated fruits and to maintain the uniformity and quality of the coffee. Possible impurities, such as sticks, leaves, stones, and other debris, were also eliminated during this step.

After the washing operation, the samples were divided into two parts. One portion was sent directly to drying (natural or dry-processed coffee) in $1 \mathrm{~m}^{2}$ sieves, which were kept suspended to approximately $1.20 \mathrm{~m}$ from the soil. This operation aided the drying step by facilitating the passage of air through the mass of fruit. The sieves were constructed with stainless steel wire mesh $\left(2 \mathrm{~mm}^{2}\right.$ mesh) and $7 \mathrm{~cm}$ tall wooden sides. The other half of the sample was dehusked using a Pinhalense brand dehusker, model DPM-02 no 928. Residues of the remaining husks, fruits broken during the operation, and insect-affected fruits were eliminated after this procedure. Then, the peeled samples were stored in 20 L plastic tanks for mucilage removal using natural fermentation for 24 hours (pulped or wet-processed coffee). After the fermentation period, coffee beans with their endocarp still attached were washed in clean water, rubbed together by hand under running water, and spread in the aforementioned sieves while remaining in full sun exposure until the coffee beans reached approximately $11 \%$ moisture (by mass).

The samples were turned approximately 20 times during the day, according to procedures by Borém (2008). After drying, coffee beans with their endocarp still attached were kept in double-leaf Kraft paper bags for a rest period of 30 to 40 days to stabilize moisture content in the coffee beans. After this period, the samples were processed (endocarp removed from the coffee grain) and conditioned in impermeable plastic bags.

The sensory analysis of the beverage was carried out by three qualified and certified tasters using the methodology for sensory evaluation of specialty coffees according to the Specialty Coffee Association of America (SCAA) protocol (SCAA 2018). In this evaluation, the fragrance/aroma, acidity, body, flavor, clean cup, sweetness, uniformity, aftertaste, balance, and overall score attributes were in the range of 6 to 10 points. The total score was constituted by the sum of 
the points conferred to each of the aforementioned attributes. Specialty coffees were those that reached a total score equal to or greater than 80 points.

The analyses of variance were performed in a triple factorial scheme, in which the factors for genotype, postharvest processing methodology, and taster were all considered fixed effects.

The groupings of the means of the attributes among genotypes were performed by the Scott-Knott criterion. The mean comparisons between the processes for each genotype were performed by the Tukey test, both at $5 \%$ probability.

The relative importance of the sensory attributes was analyzed by Singh's method (1981), which was based on the distance $\left(D^{2}\right)$ factor from Mahalanobis (Cruz et al. 2012). The relative importance was considered to have relative variability for the interpretation of the data with a univariate approach and to observe the behavior of the variation of the sensory attributes in the different evaluated processes.

A network graph of correlations was constructed from the phenotypic correlations (Rosado et al. 2017) and the sensory attributes, in which the variables with positive correlations were connected by a green line and the negatives by a red line. The thickness of the lines represents the absolute value of the correlation whereby the thicker the correlation between the variables is represented by a thicker line. The thickness of the lines was controlled by applying a cut-off value of 0.8 to more easily visualize the graph. Values that were $|\mathrm{rij}| \geq 0.8$ had their lines highlighted proportionally to the intensity of the correlation. The fine lines have correlations lower than the cut-off point of 0.8 and are not highlighted to distinguish the values.

The sensory profile was represented graphically and allowed the evaluation of the predominance of attributes in the different evaluated cultivars. All genetic-statistical analyses were processed by the GENES software (Cruz 2013), which uses heavy integration from the R software (Cruz 2016, R Core Team 2019).

\section{RESULTS AND DISCUSSION}

The results indicated the consistency of the scores awarded by the testers since they did not present significant differences by the F-test for all evaluated variables (Figure 1). The genotype and postharvest processing interaction were significant for the sensory attributes fragrance/aroma, flavor, acidity, body mass, residual taste, general balance, and total scores. Coefficients of variation were lower than $4.2 \%$, which indicates good experimental precision, and agreed with those carried out in comparable experiments using coffee (Silveira et al. 2016, Gamonal et al. 2017). Low values of coefficients of variation can be considered the primary indicator of the existence of homogeneity in the data (Gomes and Garcia 2002).

The sweetness, uniformity, and clean cup attributes were disregarded for the statistical analysis since all genotypes received a maximum score of 10 points. These attributes were tasted when the temperature of the beverage approached the ambient temperature (below $35^{\circ} \mathrm{C}$ ) during the evaluation. The tasters made an individual assessment of each cup, conceding two points per cup per attribute, with ten points being the maximum result for the set of five cups (SCAA 2018). The uniformity attribute refers to the coherence between different cups of a sample, while the clean cup attribute represents the absence of negative or poor tastes that degrade the quality of the beverage (SCAA 2018).

For the overall scores, all wet-processed coffee genotypes presented scores equal to or higher than those submitted

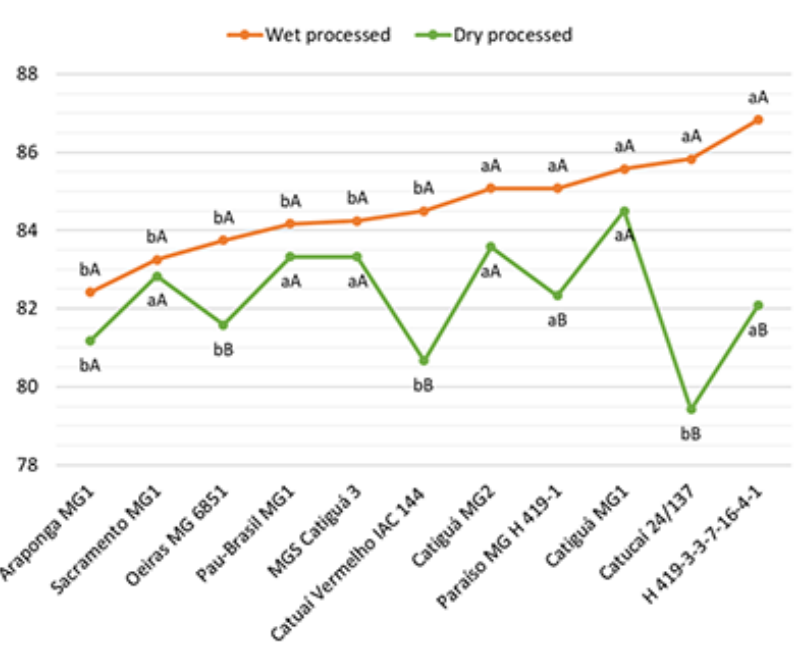

Figure 1. Total scores of the arabica coffee cultivars that underwent wet processing and dry processing in the city of Araponga, MG, Brazil, in 2017. The cultivars whose points on the graph have the same lowercase letter belong to the same group based on the Scott-Knott test at a $5 \%$ probability. The uppercase letters that follow lowercase letters are organized in columns using the Tukey test at $5 \%$ probability. 
Sensory quality of Coffea arabica L. genotypes influenced by postharvest processing

Table 1. The analysis of variance for the sensory attributes of fragrance/aroma (FrA), flavor (Flv), acidity (Acd), body (Bdy), aftertaste (Aft), balance (Bal), overall (Ovr), and total (Ttl) of genotypes of arabica coffee produced from two different postharvest processing techniques in the city of Araponga, MG, Brazil, during the 2016 season

\begin{tabular}{|c|c|c|c|c|c|c|c|c|c|}
\hline \multirow[b]{2}{*}{ FV } & \multirow[b]{2}{*}{ gl } & \multicolumn{8}{|c|}{ Means square } \\
\hline & & FrA & Flv & Acd & Bdy & Aft & Bal & Ovr & Ttl \\
\hline$B^{1}$ & 1 & 0.09 & 0.23 & 0.27 & 0.01 & 0.37 & 0.12 & 0.07 & 4.18 \\
\hline$P$ & 1 & $2.32 * *$ & $4.55^{* *}$ & $2.73^{* *}$ & $3.83 * *$ & $6.82 * *$ & $2.45^{* *}$ & $4.36^{* *}$ & $183.18^{* *}$ \\
\hline G & 10 & $0.45^{* *}$ & $0.49 * *$ & $0.31^{* *}$ & $0.18^{*}$ & $0.47^{* *}$ & $0.17^{* *}$ & $0.18^{* *}$ & $11.48^{* *}$ \\
\hline TxP & 2 & 0.05 & 0.01 & 0.01 & 0.04 & 0.02 & 0.02 & 0.01 & 0.21 \\
\hline TxPxG & 20 & 0.03 & 0.03 & 0.01 & 0.02 & 0.04 & 0.01 & 0.01 & 0.24 \\
\hline Error & 65 & 0.07 & 0.09 & 0.06 & 0.07 & 0.10 & 0.05 & 0.05 & 2.12 \\
\hline Total & 130 & & & & & & & & \\
\hline Average & & 7.64 & 7.71 & 7.53 & 7.73 & 7.67 & 7.59 & 7.57 & 83.44 \\
\hline
\end{tabular}

* and ${ }^{* *}$ significant at $5 \%$ probability, and significant at $1 \%$ probability using the $\mathrm{F}$ test, respectively.

${ }^{1}(\mathrm{~B}=$ block; $\mathrm{P}=$ process; $\mathrm{T}=$ Taster, and $\mathrm{G}=$ genotype $)$

to dry processing (Figure 1). The genotypes Catiguá MG1, Catiguá MG2, MGS Catiguá 3, and Pau-Brasil MG1 presented scores above 83 points for both processes. When submitted to dry processing, Catuaí Vermelho IAC 144, Catucaí Amarelo 24/137, Oeiras MG 6851, Paraiso MG H419-1, and H419-3-3-7-16-4-1 genotypes presented significantly lower scores (Figure 1). Some of these coffees likely have characteristics that favor fermentation when submitted to dry processing, similar to wet-processed coffees with higher volume and/or higher sugar content, among other characteristics that were not evaluated in the present study. Although the clean cup attribute was eliminated and dry-processed coffees were favored, some genotypes still presented reduced quality for dry-processed coffee. In addition, reductions in total score were found by Clemente et al. (2015) for dry-processed coffees when dried in mechanical dryers. During wet processing, two groups with different genotypes were formed according to the Scott-Knott test at $5 \%$ probability (Figure 1). The first group consisted of the genotypes H419-3-3-7-16-4-1 (86.8), Catucaí Amarelo 24/137 (85.8), Catiguá MG1 (85.6), Catiguá MG2 (85.1), and Paraiso MG H419-1 (85.1), which received scores above 85 points and were described by the SCAA as specialty coffees with an "excellent" grading classified as "special origin". The cultivars in the second group, MGS Catiguá 3 (84.2), Pau-Brasil MG1 (84.2), Catuaí Vermelho IAC 144 (84.0), Oeiras MG 6851 (83.7), Sacramento MG1 (83.2), and Araponga MG1 (82.4), also presented scores above 80 points. Notes from 80 to 85 are specialty coffees with a "very good" grading and classified as "premium" (SCAA 2018).

In the dry processing of the coffee, two groups were formed. However, the classification of some genotypes was different from what was previously described in Figure 1. The first group consisted of the genotypes Catiguá MG1 (84.5), Catiguá MG2 (83.6), MGS Catiguá 3 (83.3), Pau-Brasil MG1 (83.3), Sacramento (82.8), Paraíso MG H419-1 (82.3), and H419-3-3-7-16-4-1 (82.1). Although all wet-processed genotypes presented lower total scores than wet-processed coffees, the dry-processed Catiguá MG1, Catiguá MG2, Paraíso MG H419-1, and H419-3-3-7-16-4-1 genotypes remained in the group with higher scores. The MGS Catiguá 3 genotype, which was grouped with the genotypes with lower scores for the wet-processed coffee, was classified in the highest score group when submitted to dry processing. The second group consisted of Oeiras MG6851 (81.6), Araponga MG1 (81.2), Catuaí Vermelho IAC144 (80.7), and Catucaí Amarelo 24/137 (79.4) genotypes. The Catucaí Amarelo 24/137 cultivar, which was the second-highest grade for the wet-processed coffee, was the only genotype that presented a grade lower than 80 points (below the special quality designation) when submitted to dry processing.

These results demonstrated the potential for improving the sensory quality of new genotypes, which may present higher scores than those observed for the Catuai Vermelho IAC 144 cultivar for both wet-processed and dry-processed coffee. In addition, these varieties offer increased profitability potential for coffee operations because they show a high degree of resistance to rust. However, the genotypes with higher grades for wet-processed coffees may not be suitable for dry processing due to their reduction in beverage quality. Therefore, some genotypes can be generally recommended 
for the two processes or may be specifically considered based on the results in each of the postharvest processes (Figure 1).

The analysis of relative variability by the method of Singh (1981) classified the attributes with greater variation among the evaluated genotypes. Thus, attributes with greater relative variability were those in which the genotypes presented greater differences between the scores. However, attributes with lower variability may be considered a characteristic of the processing method, since genotypes tend to present the same scores for these attributes.

In relation to wet-processed coffees, the attribute with the greatest relative variability was acidity $(27.85 \%)$, followed by balance $(22.07 \%)$, and aftertaste (18.59\%) (Table 2). In general, coffees submitted to wet processing have higher acidity (Lima et al. 2008). However, this trend was not observed for all genotypes since there was a greater variation in acidity among them. The body attribute presented low relative variability for wet-processed coffee (2.26\%) (Table 2) along with high scores between 7.75 and 8.00 (Figure 2). These scores can be classified as "very good" or "excellent" (SCAA 2018). In general, dehusked coffees yielded a more intense beverage when the mucilage remained intact (Teixeira et al. 2015). Even with the absence of mucilage, similar results were observed for the various genotypes. For dry-processed coffees, the flavor (25.37\%), body (19.96\%), fragrance/aroma (17.37\%), and overall (15.09\%) scores were the attributes with the highest relative variability (Table 2). These results showed variability among the genotypes regarding the expression of these attributes based on the different forms of postharvest processing, which makes it possible to produce coffees with different sensory profiles from the same genotypes. The balance of the coffee presented low relative variability (2.74\%) (Table 2) for dry-processed coffee with scores between 7.33 and 7.50 (Figure 2). Although these scores were classified as "very good", they were inferior to most of those received by the other attributes. This result may be associated with reduced acidity scores since the balance takes into account the harmony between flavor, aftertaste, body, and acidity scores.

All attributes presented positive correlations with genotypic traits, with many also showing a high degree of correlation for both processes (Figure 3). The body and balance attributes presented correlations lower than 0.8 for the wet-processed and dry-processed coffees, respectively. This result agrees with the previous evaluation (Table 2), in which the body attribute presented smaller relative variability in wet processing and the balance attribute presented smaller relative variability in dry processing. In general, the genotypes that received higher marks for the other attributes did not present great differences in body in
Table 2. Relative variability of sensory quality attributes evaluated during the 2016 season in two postharvest processes using the Singh method (1981), which is based on the $D^{2}$ distance from Mahalanobis

\begin{tabular}{lcc}
\hline \multirow{2}{*}{ Attributes } & \multicolumn{2}{c}{ Relative variability (\%) } \\
\cline { 2 - 3 } & Wet-processed & Dry-processed \\
\hline Fragrance/Aroma & 8.38 & 17.37 \\
Flavor & 9.31 & 25.37 \\
Acidity & 27.85 & 9.65 \\
Body & 2.26 & 19.96 \\
Aftertaste & 18.59 & 9.81 \\
Balance & 22.07 & 2.74 \\
Overall & 11.54 & 15.09 \\
\hline
\end{tabular}

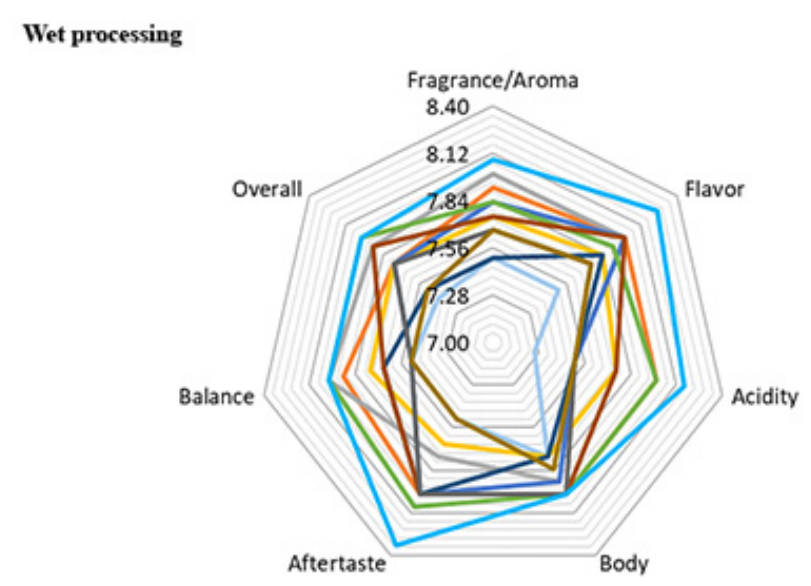

Dry processing

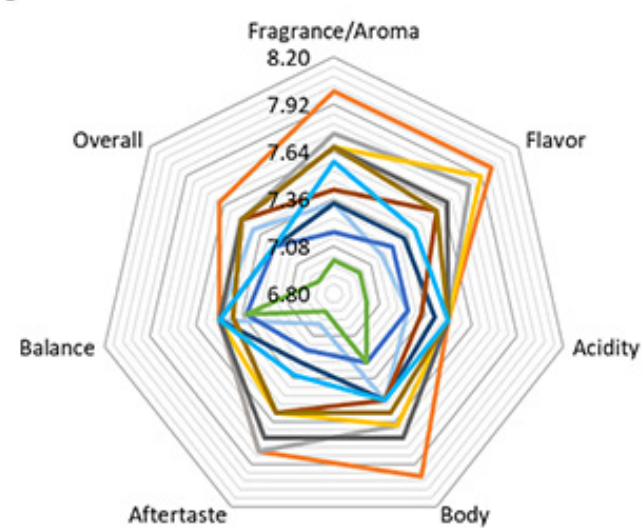

Figure 2. Sensory profile of rust-resistant coffee cultivars and the Catuaí Vermelho cultivar IAC 144, which is susceptible to rust, submitted to postharvest wet-processing and dry-processing in Araponga, MG, Brazil, in 2016. 

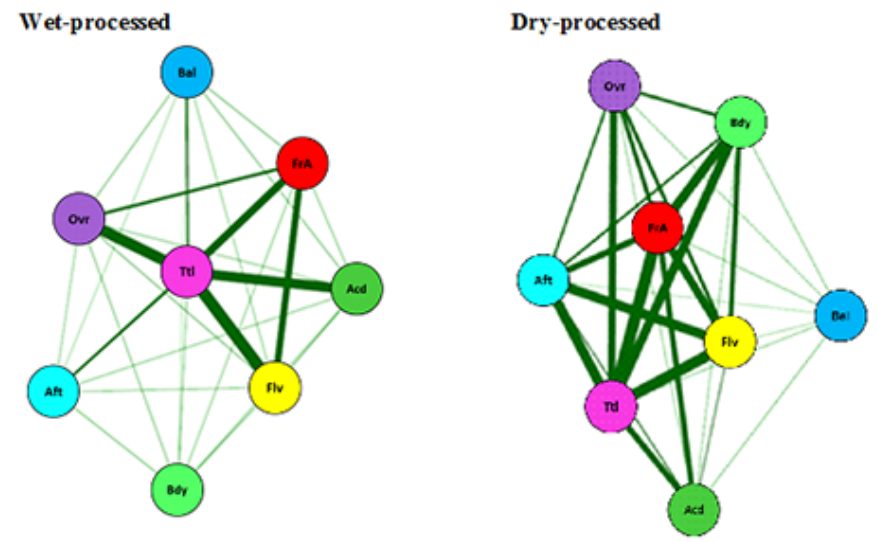

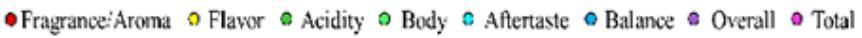

Figure 3. A network of phenotypic correlations between attributes of sensory quality for wet-processed and dry-processed genotypes evaluated in Araponga, MG, Brazil. The green lines represent a positive correlation between the variables. The thickness of the lines was controlled by applying a cut-off value of 0.8 , where only | rij $\mid \geq 0.8$ had their line thickness increased proportionally based on the intensity of the correlation. The fine lines represent correlations lower than 0.8 and are not highlighted.

the wet-processed coffee or in balance in dry-processed coffee. This result may further strengthen the hypothesis that body and balance attributes are characteristic of the wet-processed and dry-processed coffees, respectively, produced in the city of Araponga.

Carvalho et al. (2016) evaluated 10 cultivars of arabica coffee in the cities of Lavras, Patrocínio, and Turmalina and observed a higher correlation between the body attribute and the total score. However, the correlation was still lower than 0.8. Moreover, these authors found lower correlations between the attributes of body and acidity, which was likewise found in this study.

The fragrance/aroma attribute presented the highest number of high correlations. The wet-processed coffee had correlations above 0.8 for flavor, overall, and total score, while the dry-processed coffee demonstrated correlations below 0.8 only with the balance attribute (Figure 3). The genotypes Araponga MG1, Catiguá MG1, Catiguá MG2, MGS Catiguá 3, Pau-Brasil MG1, and Sacramento MG1 showed little or no difference in the attribute scores between the two processes. However, the superiority of the pulped coffee was identified when a significant difference was observed (Figure 4). However, the genotypes Catuaí Vermelho IAC 144, Catucaí Amarelo 24/137, Oeiras MG 6851, Paraíso MG H419-1, and H419-3-3-7-16-4-1 showed greater sensitivity to different types of processing (Figure 5). The genotypes Catucaí Amarelo 24/137 and H419-3-
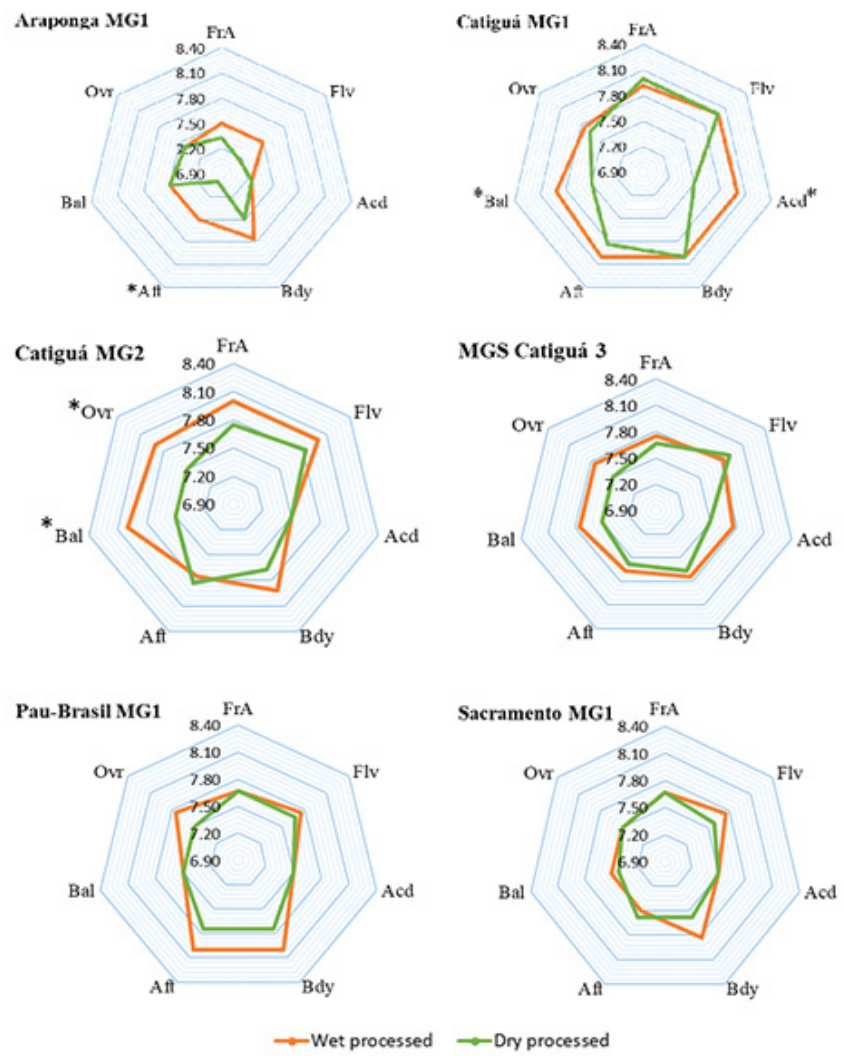

Figure 4. Sensory profile of arabica coffee cultivars submitted to wet processing and dry processing in the city of Araponga, MG, Brazil, in 2017. Fragrance/Aroma (FrA), Flavor (Flv), Aftertaste (Aft), Acidity (Acd), Body (Bdy), Balance (Bal), and Overall (Ovr). The asterisk (*) indicates that the score of the attribute between the type of processing (wet or dry) differs statistically by the Tukey test at $5 \%$ probability. 
3-7-16-4-1 presented significantly higher scores for all sensory attributes after undergoing wet processing.

Coffee fruits may undergo internal damage related to protein degradation during the postharvest process, which can produce beverages with varying quality (Livramento et al. 2016). The wet-processed coffees often show higher tolerance to drying, which is evidenced by the greater activity of antioxidative enzymes and the better physiological performance than those processed using dry processing (Taveira et al. 2012). Perhaps some genotypes show greater resistance to these types of cellular damage and, therefore, present greater stability in drink quality based on the type of processing (Borém et al. 2013, Oliveira et al. 2013). Therefore, special precautions should be taken in the recommendation of cultivars so that the level of processing adopted in the field is considered.

Therefore, it is implied that there is an interaction between genotype and the type of postharvest processing for all sensory attributes. The genotypes present higher sensorial scores when submitted to wet processing than when submitted to dry processing. All the genotypes with some degree of rust resistance in the present work had the potential for the production of special coffees with different sensorial profiles independent of the postharvest processing. The only exception was the cultivar Catucaí Amarelo 24/137, with a score below 80 points for natural coffee.

\section{ACKNOWLEDGMENTS}

The authors greatly appreciate the financial support provided by the Foundation for Research Support of the State of Minas Gerais (FAPEMIG), the Coordination for the Improvement of Higher Education Personnel (CAPES), and the Research Consortium of Coffee. We would also like to thank student workers Diondevon Rocha de Oliveira, André Fraga Sudário, Pedro Henrique Silva Ferreira, and Vanessa Vitoriano Pereira for their contributions during the field experiments.

\section{REFERENCES}

Borém FM (2008) Processamento do café. In Borém FM (ed) Pós-colheita do café. UFLA, Lavras, p. 127-158.

Borém FM, Oliveira PD, Isquierdo EP, Giomo GS, Saath R and Cardoso RA (2013) Microscopia eletrônica de varredura de grãos de café submetidos a diferentes formas de processamento e secagem. Coffee Science 8: 227-237.

Carvalho AM, Rezende JC, Rezende TT, Ferreira AD, Rezende RM, Mendes ANG and Carvalho GR (2016) Relationship between the sensory attributes and the quality of coffee in different environments. African Journal of Agricultural Research 11: 3607-3614.
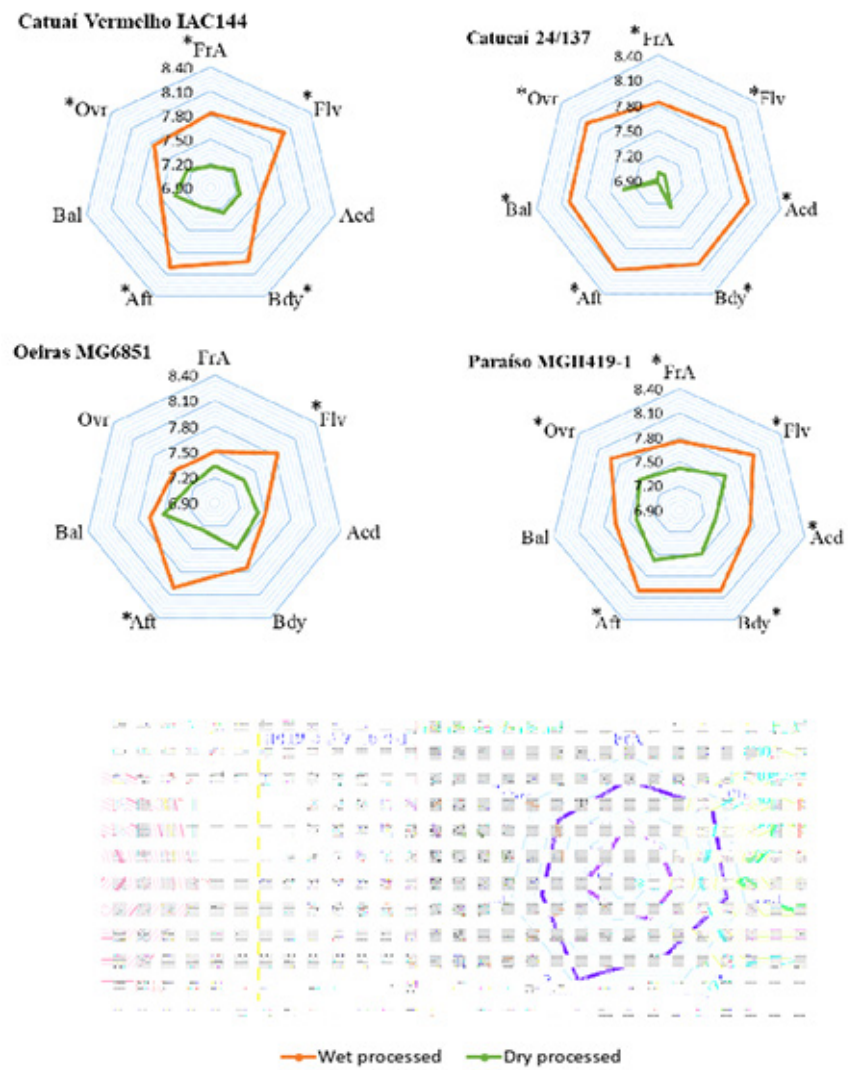

Figure 5. Sensory profile of arabica coffee cultivars submitted to wet processing and dry -processing in the city of Araponga, MG, Brazil, in 2017. Fragrance/Aroma (FrA), Flavor (Flv), Aftertaste (Aft), Acidity (Acd), Body (Bdy), Balance (Bal), and Overall (Ovr). The asterisk $\left({ }^{*}\right)$ indicates that the score of the attribute between the type of processing (wet or dry) differs statistically by the Tukey test at $5 \%$ probability.
Clemente ACS, Cirillo MA, Malta MR, Caixeta F, Pereira CC and Rosa SDVF (2015) Operações pós-colheita e qualidade físico-química e sensory de cafés. Coffee Science 10: 233-241.

Costa C and Bessa F (2014) Cafés especiais do Brasil atendem às diferentes demandas mundiais. Available at: <http://www. consorciopesquisacafe.com.br/index.php/imprensa/noticias $>$. Accessed on September 24, 2019.

Cruz CD (2013) GENES - a software package for analysis in experimental statistics and quantitative genetics. Acta Scientiarum 35: 271-276.

Cruz CD (2016) GENES Software - extended and integrated with the R, Matlab and Selegen. Acta Scientiarum 38: 547-552. 
Cruz CD, Regazzi AJ and Carneiro PCS (2012) Modelos biométricos aplicados ao melhoramento genético. UFV, Viçosa, 514p.

Gamonal LE, Vallejos-Torres G and Lopez LA (2017) Sensory analysis of four cultivars of coffee (Coffea arabica L.), grown at different altitudes in the San Martin region - Peru. Ciência Rural 47: 1678-4596.

Gomes FP and Garcia CH (2002) Estatística aplicada a experimentos agronômicos e florestais. FEALQ, Piracicaba, 305p.

Guimarães PTG, Garcia AWR, Alvares VVH, Prezotti LC, Viana AS, Miguel AE, Malavolta E, Corrêa JB, Lopes AS, Nogueira FD, Monteiro AVC and Oliveira JÁ (1999) In Ribeiro AC, Guimarães PTG and Alvarez VVH (eds) Recomendações para o uso de corretivos e fertilizantes em Minas Gerais - 5a Aproximação. CFSEMG/UFV, Viçosa, p. 289-302.

Lima MV, Vieira HD, Martins ML and Pereira SF (2008) Preparo do café despolpado, cereja descascado e natural na região sudoeste da Bahia. Revista Ceres 55: 124-130.

Livramento KG, Borém FM, José AC, Santos AV, Livramento DE, Alves JD and Paiva LV (2016) Proteomic analysis of coffee grains exposed to different drying process. Food Chemistry 221: 1874-1882.

Oliveira PD, Borém FM, Isquierdo EP, Giomo GS, Lima RR and Cardoso RA (2013) Physiological aspects of coffee beans, processed and dried through different methods, associated with sensory quality. Coffee Science 8: 211-220.

Proença M (2018) Araponga canta alto. Revista espresso. Café editor, Jardim Paulista - São Paulo. Available at: <http://revistaespresso. com.br/2019/02/28/araponga-canta-alto/>. Accessed in September 23, 2019.
R Core Team (2019). R: A language and environment for statistical computing. R Foundation for Statistical Computing, Vienna, Austria. URL https://www.R-project.org/.

Rosado RDS, Rosado LDS, Cremasco JPG, Santos CEM, Dias DCFS and Cruz CD (2017) Genetic divergence between passion fruit hybrids and reciprocals based on seedling emergence and vigor. Journal of Seed Science 39: 417-425.

Sakiyama NS, Martinez HEP, Tomaz MA and Borém A (2015) Café arábica do plantio à colheita. UFV, Viçosa, 316p.

SCAA - Specialty Coffee Association of America (2018) Available at: $<$ https://sca.coffee/research/protocols-best-practices/>. Accessed on September 24, 2019.

Silveira AS, Pinheiro ACT, Ferreira WPM, Silva LJ, Rufino JLS and Sakiyama NS (2016) Sensory analysis of specialty coffee from different environmental conditions in the region of Matas de Minas, Minas Gerais, Brazil. Revista Ceres 63: 436-443.

Singh D (1981) The relative importance of cheracteres affecting genetic divergence. The Indian Jornal of Genetics and Plant Breeding 41: 237-245.

Taveira JHS, Rosa SDVF, Borém FM, Giomo GS and Saath R (2012) Perfis proteicos e desempenho fisiológico de sementes de café submetidas a diferentes métodos de processamento e secagem. Pesquisa Agropecuária Brasileira 47: 1511-1517.

Teixeira MM, Filho AFL, Oliveira MVM, Silva FAP and Moreira RMG (2015) Colheita e pós-colheita. In Sakiyama NS, Martinez HEP, Tomaz MA and Borém A (eds) Café arábica do plantio à colheita. UFV, Viçosa, p. 216-249. 